https://doi.org/10.18485/iipe_response2covid19.2021.ch25

\title{
INTERNATIONAL STUDENT MOBILITY AND COVID-19 STUDENTS' EXPERIENCES: THE RESPONSES OF HOST INSTITUTIONS AND COUNTRIES
}

\author{
Georgina Kasza ${ }^{1}$ \\ Gábor Dobos ${ }^{2}$ \\ Kitti Köves ${ }^{3}$ \\ Zsuzsa M. Császár ${ }^{4}$
}

\begin{abstract}
The COVID-19 epidemic has brought unprecedented challenges for international students and their host institutions and countries as well. This study focuses on two main areas: the international students' experiences during the pandemic and the measures that host universities and national governments and scholarship agencies have taken. Firstly, the study provides an overview of international student mobility and its current tendencies, including Hungarian trends. Afterwards, we analyse the available reports and statistics related to the pandemic's impact on international student mobility in the major host countries and examine the policies introduced on national and institutional levels. By comparing the main host countries' measures and their impacts on international student mobility, we could identify good practices regarding handling the pandemic situation in relation to student mobility. The empirical part of the research was conducted in Hungary among degree-seeking international students. Following March 2020, the transition to distance education and further health safety rules significantly influenced international students' studies and experiences. The
\end{abstract}

\footnotetext{
${ }^{1} \mathrm{PhD}$, senior internationalisation analyst, Tempus Public Foundation, H-1077 Budapest, Hungary, georgina.kasza@tpf.hu.

${ }^{2}$ Study in Hungary director, Tempus Public Foundation and PhD student, University of Pécs, Doctoral School of Earth Sciences, H-1077 Budapest, Hungary, gabor.dobos@tpf.hu.

${ }^{3}$ PhD student, University of Pécs, Doctoral School of Earth Sciences, Hungary, koves.kitti@gmail.com.

${ }^{4}$ PhD, Associate Professor, Department of Political Geography and Development and Regional Studies, University of Pécs, Hungary, cszsuzsa@gamma.ttk.pte.hu.
} 
research's main aim was to explore the opinions and experiences of international students studying with scholarships in Hungary in connection with being an international student during the epidemic. The research results provide insight into students' digital and IT preparedness; student experiences during a pandemic; participation in distance education, learning experiences; and student services provided by universities. The importance of this study lies in the fact that international students' experiences serve as feedback for host universities and countries; it evaluates the executed measures and provides recommendations for further adjustments.

Keywords: COVID-19, international students, experiences, response, impacts

\section{INTRODUCTION}

The pandemic suddenly affected all aspects of life in our globalized world. From one way to the next, the long supply chains were disrupted, air traffic was shut down, cross-border travel restrictions and curfew were introduced in many countries, and the educational institutions were closed, teaching and learning moved to the virtual space. Naturally, these caused an immediate effect on the internationalization of higher education, breaking the long-lasting trends and facing challenges all stakeholders, including universities, students, academics, staff, policymakers and supporting agencies. COVID-19 has impacted not just the physical mobility of international students and the universities' sudden switch to distance education but also the higher education institutions' research activities (HEIs). It caused restrictions on international researchers' mobility, the closures of labs, the postponement or cancellation of scientific conferences, slowed down international collaborations and endangered the completion of scientific projects. However, we can consider as a positive aspect the involvement of HEls in the research of COVID-19 and its impacts. Many universities played and still play an important role in finding solutions in various affected areas. Accordingly, this study focuses on a specific aspect, namely the international students' situation in Hungary during the pandemic.

In Hungary, universities suddenly moved to distance education in the middle of March 2020. The switch to online learning significantly influenced higher education institutions. The transition was unprecedented and unexpected; the digital preparedness of higher education institutions, teachers, and students was not adequate. However, the various online platforms were well-known in Hungarian universities; their use was not commonly used and instead connected to each teacher's work or study program. It is also important to highlight that most international students had not participated in distance or online learning before the transition. 


\section{TRENDS IN INTERNATIONAL STUDENT MOBILITY IN THE LAST TWO DECADES}

Recent data of UNESCO shows the number of international students doubled between 2001 and 2018, increasing from 2.1 billion to 5.5 billion (UIS, 2021). The trend is obvious although there have already been some predictions that the annual average increase of 5.5 per cent of the last decade will not be sustainable. The British Council warned the increase would decrease to a 1.7 per cent growth due to the enormous capacity-building efforts in the field of education of India and China. The OECD analysis also showed a common misunderstanding about the stable increase in international students' mobility. The growth rate is actually quite hectic, and in 2004 and 2012 it did not even reach 2 per cent (1.6 and 1.7), while it exceeded 12 per cent (12.8) in 2002.

Figure 1. Number and annual growth rate of international students

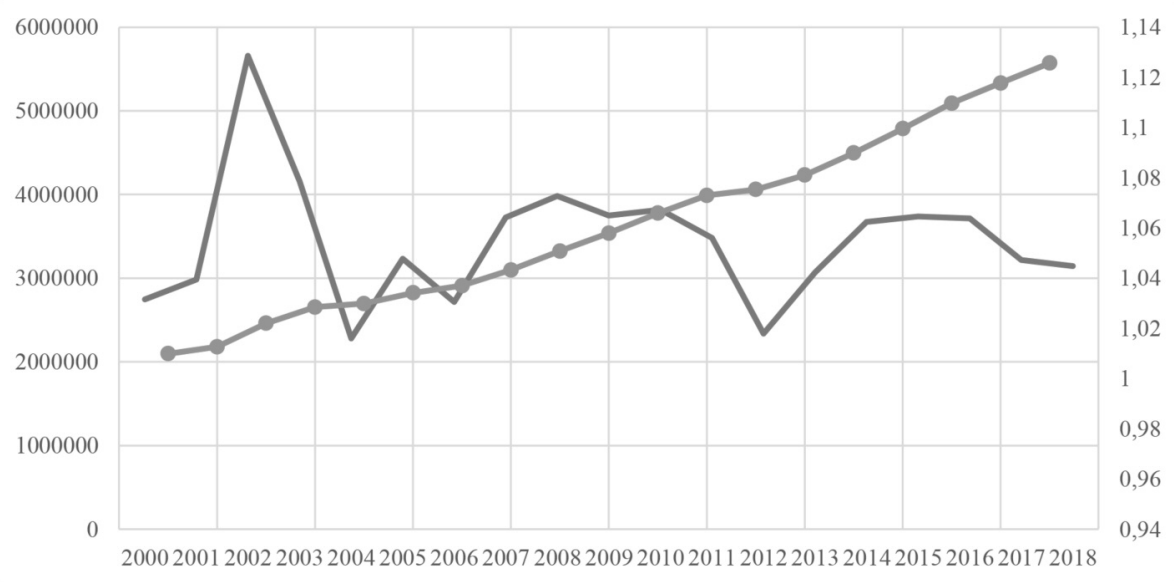

Source: UNESCO, data downloaded 20.05.2021

Although data also show that the main engines of growth are still China and India, there have been changes in the top ten sending and hosting countries. While the US, the UK and Australia remained the first three hosting countries, their market share decreased by 7 per cent. Germany, France, Canada, Japan, and China kept their positions, and only one new country joined. Turkey rose into the top ten, replacing Malaysia. However, the positions remained largely intact despite a 5\% decrease in market share between 2014 and 2018. 
Table 1. Top ten hosting countries and their share of international students

\begin{tabular}{|l|r|c|l|r|c|}
\hline $\begin{array}{c}\text { Host countries } \\
2014\end{array}$ & \multicolumn{1}{|c|}{ Number } & Share & $\begin{array}{c}\text { Host countries } \\
2018\end{array}$ & Number & Share \\
\hline USA & 842,384 & $22.3 \%$ & USA & 987,313 & $26.1 \%$ \\
\hline UK & 428,724 & $11.4 \%$ & UK & 452,079 & $12.0 \%$ \\
\hline Australia & 266,048 & $7.0 \%$ & Australia & 444,514 & $11.8 \%$ \\
\hline France & 235,123 & $6.2 \%$ & Germany & 311,738 & $8.3 \%$ \\
\hline Russia & 213,347 & $5.6 \%$ & Russia & 262,416 & $6.9 \%$ \\
\hline Germany & 210,542 & $5.6 \%$ & France & 229,623 & $6.1 \%$ \\
\hline Canada & 164,274 & $4.3 \%$ & Canada & 224,548 & $5.9 \%$ \\
\hline Japan & 132,685 & $3.5 \%$ & Japan & 182,748 & $4.8 \%$ \\
\hline China & 108,217 & $2.9 \%$ & China & 178,271 & $4.7 \%$ \\
\hline Malaysia & 99,648 & $2.6 \%$ & Turkey & 125,138 & $3.3 \%$ \\
\hline TOP10 sum 2014 & $2,700,992$ & $71.5 \%$ & TOP10 sum 2018 & $3,398,388$ & $90.0 \%$ \\
\hline $\begin{array}{l}\text { All international } \\
\text { student 2014 }\end{array}$ & $3,776,751$ & & $\begin{array}{l}\text { All international } \\
\text { student 2018 }\end{array}$ & $5,571,402$ & \\
\hline
\end{tabular}

Source: UNESCO 
Table 2. Top ten sending countries and their share of international students

\begin{tabular}{|c|c|c|c|c|c|}
\hline \begin{tabular}{|c|} 
Sending \\
countries 2014 \\
\end{tabular} & Number & Share & \begin{tabular}{|c|} 
Sending \\
countries 2018 \\
\end{tabular} & Number & Share \\
\hline China & 770,784 & $22.3 \%$ & China & 993,367 & $17.7 \%$ \\
\hline India & 215,954 & $11.4 \%$ & India & 375,055 & $8.1 \%$ \\
\hline Germany & 118,498 & $7.0 \%$ & Germany & 122,538 & $8.0 \%$ \\
\hline $\begin{array}{c}\text { Korea (Republic } \\
\text { of) }\end{array}$ & 110,106 & $6.2 \%$ & Vietnam & 108,527 & $5.6 \%$ \\
\hline Saudi Arabia & 84,195 & $5.6 \%$ & $\begin{array}{c}\text { Korea (Republic } \\
\text { of) }\end{array}$ & 101,774 & $4.7 \%$ \\
\hline France & 82,073 & $5.6 \%$ & France & 99,488 & $4.1 \%$ \\
\hline Nigeria & 79,467 & $4.3 \%$ & USA & 84,349 & $4.0 \%$ \\
\hline USA & 77,963 & $3.5 \%$ & Kazakhstan & 83,503 & $3.3 \%$ \\
\hline Kazakhstan & 66,998 & $2.9 \%$ & Nepal & 81,917 & $3.2 \%$ \\
\hline Malaysia & 62,504 & $2.6 \%$ & Saudi Arabia & 77,406 & $2.2 \%$ \\
\hline TOP10 sum 2014 & $1,668,542$ & $71.5 \%$ & $\begin{array}{l}\text { TOP10 sum } \\
2018\end{array}$ & $2,127,924$ & $61.0 \%$ \\
\hline $\begin{array}{l}\text { All international } \\
\text { students, } 2014\end{array}$ & $3,776,751$ & & $\begin{array}{l}\text { All international } \\
\text { students, } 2018\end{array}$ & $5,571,402$ & \\
\hline
\end{tabular}

Source: UNESCO

Compared to the hosting countries, there were significant changes among the sending ones. Again, the top two countries (India, China) remained unchanged. Nigeria and Malaysia lost their positions against Vietnam and Nepal. Also, there is an interesting trend that all the bigger hosting countries have managed to increase the number of international students. There are two sending states (Saudi Arabia and Korea) where a substantial decrease or only a slight increase (Germany) can be seen.

These findings show that international students have become increasingly diverse, and they study in more and more countries. On a regional level, the same data also indicate that the two winners of this diversification are Australia and Central and Eastern Europe. The share of international students increased by 2.6 
per cent in the first region and by 0.94 in the second, while Western Europe and North America experienced a major loss (-2.38), and the Arab and Sub-Saharan states experienced a slight decrease (-0.6) in their market share.

Similarly to global trends, there has been a stable and continuous increase in the number of international students in Hungarian higher education since the millennium (Figure 2.). In 2001, the number of international students was 11,783, and it has increased by 326 per cent in almost two decades. The current population $(38,422)$ is almost as large as the whole student population of two bigger Hungarian universities. The increase in the annual progress rate itself is also considerable. The 3.4 per cent of growth in 2000 increased to 13.4 per cent by 2019 . The expansion has been continuous since 2005 thanks to, among other factors, European integration, the Bologna Process, national policies and initiatives (Stipendium Hungaricum program, "Eastern and Southern Opening" policy towards Asian and African countries), and the active engagement of the Hungarian higher education institutions in promoting the country in the global market.

Besides the dynamic growth of the international student population, the number of sending countries is increasing as well. As a combined effect of these developments, Hungary has become an increasingly significant study destination in Europe among international students. (Figure 2.)

Regarding the potential 200 sending countries (193 independent, 4 associated, 8 'de facto', and 3 states with disputed sovereignty), Hungary had students from 152 countries in 2013/14, from 160 countries in 2016/17, and from 164 countries in $2017 / 18$. The distribution of international students by country follows the population of the sending state. Countries with a large population (app. 100+ billion) evidently have greater international student numbers globally and in Hungary as well. Some of them are developed countries like Germany, the US, Japan, and the Republic of Korea. The share of international students from less developed or developing states like Nigeria, Turkey, China, and Iran is influenced by other driving forces: development policies and the lack of or insufficient capacities. In Hungary, there is a special group of foreign students. They are from neighbouring countries and the Hungarian ethnic minorities. They study in Hungarian and are financed by the Hungarian government. Therefore, this analysis does not include them. 
Figure 2. International students in the Hungarian higher education by sending country (2019)

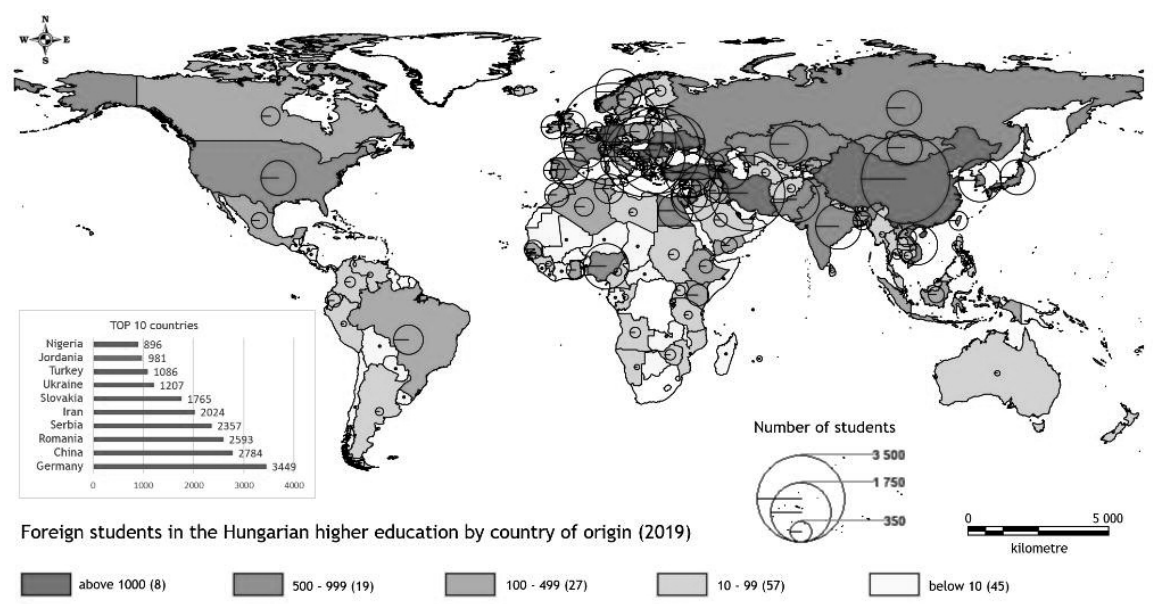

Source: Hungarian Higher Education Information System, 2019/2020

\section{RESEARCH BACKGROUND AND INTERNATIONAL EXPERIENCES}

In 2020, the outbreak of the COVID-19 pandemic brought unprecedented challenges in all areas of life, which had a major impact on higher education institutions and international mobility. Universities have been forced to introduce distance learning and other innovative, hybrid methods to provide education. Based on a survey of the International Association of Universities (IAU) conducted in 109 countries among $424 \mathrm{HEIs}$, 59\% of them stopped all campus activities in person in March-April 2020. In the developed regions (America, Europe, Asia \& Pacific), it meant a switch to distance teaching and learning, while in Africa, it led to the suspension (43\%) or cancellation (24\%) of teaching for the spring academic period (Marinoni et al., 2020). The sudden shift from face-to-face to distance education raised issues such as the preparedness of the teaching staff (IT competence and different pedagogical methods for online teaching), the matter of access for students (available steady internet connection and hardware), and also their coping ability with the new circumstances (isolation, online learning).

When discussing the pandemic-related measures influencing international student mobility, we need to distinguish measures introduced by the governments and by HEls. Generally speaking, government measures are universal, and they affect 
the lives of all people in the country. In the case of this pandemic situation, these meant border control, national or local lockdown, curfew, non-essential shop closing, shift to online education and home office, and various health safety rules such as quarantine, social distancing, mask-wearing, etc. Border control and quarantine measures primarily influence the arrival of incoming, future international students, while the listed further measures affect the study and living abroad experiences of those who have already started their mobility program. Governmental support concerning higher education and student mobility varies by country. The most common one is related to the completion of the academic year by prolonging the study period, extending the validity of resident permits, and students' cards; direct financial assistance for HEls or students was a less typical form of support (Marinoni et al., 2020). Six EU member states reported they were able to provide financial help to disadvantaged international students, and there are examples from Japan, New Zealand, and some regions in Australia (European Migration Network, 2020).

Student mobility became significantly affected by health protection measures related to country closures and entry restrictions. Currently available data show different situations in the larger host countries regarding the change in international students' numbers due to the COVID-19 epidemic as the 2020 fall academic year has begun. The British were able to increase the number of their international students despite the pandemic; the number of students admitted from outside the EU increased by 9 per cent. However, EU students' numbers mainly declined because of another factor, namely Brexit (UCAS, 2020). The German Academic Exchange Service (DAAD) reports that the overall number of international students increased last year in Germany, although there was a 20 per cent drop in first-year students from abroad last summer semester. International students who wished to study in Germany had to deal with a strict visa policy, which caused many of them not to be able to enter the country despite having been admitted (DAAD, 2021). Other host countries were less fortunate. A significant decrease in the number of international students was reported in the United States, a 43 per cent decline among first-year international students and a 16 per cent decrease in international students' total number (Baer \& Martel, 2020). In Australia, the number of enrolled international students fell by 12 per cent between March and October 2020 (Hurley, 2020), and Canada experienced a year-on-year drop of 17 per cent in international student enrolment based on the data of the Canadian Bureau for International Education.

As a service provider, HEls were and continuously are the main respondents for taking care of those international students, who were already on-site when the health risks arose by giving them up-to-date information on the local development of the pandemic and the introduced health safety measures, also by delivering technical (IT devices and software), financial, mental, and health care support and 
helping them return home. HEls play a central role in communication and sharing information with international students. By collaborating with other universities and national authorities (education, immigration, health), they are able to gather all the information students need and also to represent their interests and report major issues which require actions from the higher level of administration.

Studies are emphasizing the vulnerability of international students during COVID19. These young adults are living far away from home and facing unseen challenges caused by the pandemic: limited access to information in English, the lack of proper health insurance, the lack of financial and mental support, issues with housing and returning home, and even racial discrimination in the case of Asian and Italian students (Bilecen, 2020; Firang, 2020; Morris et al., 2020). An early report from Erasmus Student Network (ESN) examined the health effects and hardships international students suffered from and found that $41.2 \%$ of the respondents experienced anxiety and stress to a great or very great extent. Similarly, 20.8\% experienced feelings of isolation and social exclusion (Gabriels \& Benke-Aberg, 2020).

At the same time, universities had to face various challenges regarding the recruitment of future students. Traditional education fairs were cancelled, and prospective students became uncertain regarding their mobility. In spring 2020, reports were carried out on the attitude changes of students who originally intended to study abroad, but the COVID-19 outbreak significantly influenced their study plans. For example, Studyportal found that the majority of their questionnaire respondents think that the virus outbreak is likely (31\%) and very likely (33\%) to affect their studies. Students' major concerns were the possible travel restrictions, changes in their families' financial situation, and the inability to take part in exams required for university application (Studyportal, 2020). The Quacquarelli Symonds (QS) did a similar thing among prospective international students. They reported that nearly half of the respondents decided to postpone their enrollment, 6-9\% intended to study in a different country, 4-9\% gave up on studying abroad, and 32-44\% indicated other options without further explanations. However, these could include enrollment in an online course or the choice of a domestic university instead (QS, 2020).

\section{RESEARCH GOALS, METHOD AND LIMITATIONS}

The research aims to explore the experiences and opinions of international students on distance education and student life during the first wave of the pandemic. Besides, the survey aims to analyse what difficulties international students faced, how the pandemic affected teaching and learning, and what kind of support services universities provided. Following the pandemic outbreak, a multitude of studies have been published on the immediate and short-term impact 
of the COVID-19 pandemic on higher education institutions and students (Farnell et al., 2021). In addition, several surveys have examined the effect on teaching and learning, the social dimension of higher education, international student mobility, as well as system- and institutional-level changes, and more studies have focused on the transition, switch to distance learning at universities (Erasmus Student Network, 2020; Hargitai, Sasné Grósz, \& Veres, 2020; Marinoni, van’t Land, \& Jensen, 2020; Farnell et al., 2021).

The research applied a quantitative method using an online questionnaire sent to international students studying in Hungary. Drawing upon more studies carried out in 2020 by university networks, student organizations and researchers (HÖOK, 2020; ESN, 2020; QS, 2020), the online questionnaire consists of the following main parts:

- the social and educational background of international students,

- satisfaction with higher education institutions and various services provided by universities and other organizations,

- students' opinions about the various systematic and institutional factors related to the pandemic and distance education.

The data collection was achieved during the first wave of the pandemic. The international students could respond in June and July 2020. By this date, international students had experienced several months of distance education and a quarantine period. As data analysis tools, descriptive and explanatory methods were applied.

Regarding the population, the target group was the group of international students studying in Hungary in the framework of the Stipendium Hungaricum (SH) program. In the academic year of 2020/2021, the total number of 9,046 degreeseeking SH students studied in Hungary: nearly 40 per cent in undergraduate programs, 43 per cent at master level, and 17 per cent at the doctoral level; the rate of Stipendium Hungaricum students compared to the overall number of international students is 28 per cent. The online questionnaire was sent to all $\mathrm{SH}$ students. Due to the high response rate, 7,994 respondents were included in the sample after data cleansing.

Table 3. The main indicators related to the educational and social background of the target group

\begin{tabular}{|l|c|c|c|c|}
\hline & \multicolumn{2}{|c|}{ Sample } & \multicolumn{2}{c|}{ Population (2019/2020) } \\
\hline Female & 3,501 & $44 \%$ & 3,828 & $42 \%$ \\
\hline Male & 4,493 & $56 \%$ & 5,207 & $58 \%$ \\
\hline Total & 7,994 & $100 \%$ & 9,035 & $100 \%$ \\
\hline
\end{tabular}




\begin{tabular}{|l|c|c|c|c|}
\hline & \multicolumn{2}{|c|}{ Sample } & \multicolumn{2}{c|}{ Population (2019/2020) } \\
\hline Age (mean) & 25.9 years old & 24.8 years old & & \\
\hline Study levels & & & & $40 \%$ \\
\hline Undergraduate students & 3,250 & $41 \%$ & 3,644 & $36 \%$ \\
\hline Master students & 2,820 & $35 \%$ & 3,239 & $7 \%$ \\
\hline $\begin{array}{l}\text { Students at integrated } \\
\text { master programs }\end{array}$ & 327 & $4 \%$ & 612 & $17 \%$ \\
\hline PhD/DLA students & 1,493 & $19 \%$ & 1,534 & \\
\hline
\end{tabular}

Regarding the regional composition of the total sample, the majority of responding students, nearly 30 per cent came from West Asian countries, and the proportions of East Asian and South Asian students were significant. Table 3 shows the connection between the population and sample; a balanced sample allows for a reliable exploration of different perspectives and questions, and general conclusions can be drawn based on the results.

Table 4. International students by sending regions $(\mathrm{N}=7,994)$

\begin{tabular}{|l|c|}
\hline \multicolumn{1}{|c|}{ Sending regions } & Percent \\
\hline Western Asia & $29 \%$ \\
\hline Eastern Asia & $12 \%$ \\
\hline Southern Asia & $11 \%$ \\
\hline Northern Africa & $10 \%$ \\
\hline South-eastern Asia & $8 \%$ \\
\hline Central Asia & $6 \%$ \\
\hline South America & $5 \%$ \\
\hline Eastern Europe & $4 \%$ \\
\hline Eastern Africa & $4 \%$ \\
\hline Southern Europe & $4 \%$ \\
\hline
\end{tabular}




\begin{tabular}{|l|c|}
\hline \multicolumn{1}{|c|}{ Sending regions } & Percent \\
\hline Western Africa & $3 \%$ \\
\hline Southern Africa & $2 \%$ \\
\hline Central America & $1 \%$ \\
\hline Middle Africa & $1 \%$ \\
\hline
\end{tabular}

Some limitations of this study should be mentioned as well. The survey analysed the immediate impact of the pandemic and did not assess the short- and mediumterm impact. Therefore, the changes of the next academic years have to be continuously examined. Furthermore, since the sample selected for the survey was specifically degree-seeking students who were studying in Hungary with the support of SH scholarship, the results may not be applicable to short-term mobility and selffinanced international students. The study examined the impact from the student perspective only. Therefore, the experiences of teaching staff should also be involved to get a more accurate picture.

\section{RESEARCH RESULTS}

\section{International students' digital background for online learning}

During the first wave of the pandemic, students' digital competency was an actual and critical issue, and the main topic of more international and Hungarian studies (Hargitai, Sasné Grósz, \& Veres, 2020; ESN, 2020). The studies focusing on the Hungarian context examined the workload of teachers and students during the pandemic, students' learning experiences, and changes in students' lives (Hargitai, Sasné Grósz, \& Veres, 2020). The related studies also proved that the workload of teachers and students had increased, and they spent more time learning and teaching than before the pandemic outbreak. The reports have drawn attention to the importance of self-regulated learning and the development of teachers and students' digital competencies.

Regarding the digital background, the following dimensions were analysed:

- the quality of IT tools, internet access;

- the use of learning management and video-communication platforms;

- creating a dedicated learning and workspace. 
Quality IT gadgets and adequate internet access were the most critical conditions for learning during the pandemic. As regards IT tools, the laptop and smartphones were the most commonly used learning tools. Nearly $95 \%$ of international students said they had a laptop. However, $41 \%$ said they used it for distance learning. Regarding smartphones, 92 per cent owned the tool, and 36 per cent of international students used their smartphones for distance education. These results indicate that access to online learning tools was not a challenge. However, it is critical to examine the quality of the various tools. The results show that though many international students had their own IT tools, only a small percentage of them used these gadgets for online learning. The survey also examined the question of internet access. Thirty-three percent of students reported slow and limited internet access; however, only a small percentage of students were unable to access the internet, and sixty percent had good quality internet.

In most Hungarian higher education institutions, online platforms had been widely known before the switch to distance education, but they had not been integrated into everyday teaching practice. Higher education institutions could recommend what learning management and video communication platforms were used for distance education during the first wave. The most commonly applied platforms were Microsoft Teams (56\%), Zoom (47\%), Skype (36\%), Neptun Elearning (35\%), and Moodle (31\%). International students can quickly learn to use these platforms; nearly 8 per cent considered that they had difficulties using them.

The pandemic has negatively affected students' access and study progress and strengthened the various forms of inequality. Specifically, the switch to distance learning is likely to make digital inequalities more visible. Therefore, it is crucial to analyse the students' digital competencies and skills and create a designated learning space at their residence. Nearly 21 per cent of international students evaluated that they had had difficulties creating the learning and workspace, so they had not had quiet, adequate learning space for distance education. Another dimension of this question is that due to the closing of dormitories, hostels and problems with paying for rented flats or rooms, 10 per cent of respondents had difficulties with their accommodation or had to find alternative accommodation arrangements.

\section{The impact of the pandemic on teaching and learning}

The pandemic has also greatly affected the learning environment, teaching methods, and learning content. The research examined these changes in learning and teaching, which can be well assessed from international students' perspectives. 
The pandemic had a significant impact on international students' studies. On average, 63 per cent of international students considered that the pandemic significantly influenced their studies, 18 per cent said that their studies were not affected or affected to a lesser extent, and only 19 per cent evaluated this change as moderate.

Regarding fields of education, there is a significant correlation between the study field and the evaluation. Perhaps unsurprisingly, international students studying Computer Science evaluated that the pandemic had not affected their studies at all or even not moderately. In contrast, only a small proportion of international students in the Medical and Health Sciences and Teacher Training programs felt that the pandemic had not affected their studies. Besides the specificities of fields of education, the structure of study programs can be identified as a cause. In practice-oriented courses, the change was more noticeable due to the closure of campuses and places of internships. Thus, the switch to online learning was more difficult in the field of education with practical elements.

Figure 3. In your view, how has the pandemic been affecting your studies this semester? $(N=6,570, p<0.05)$

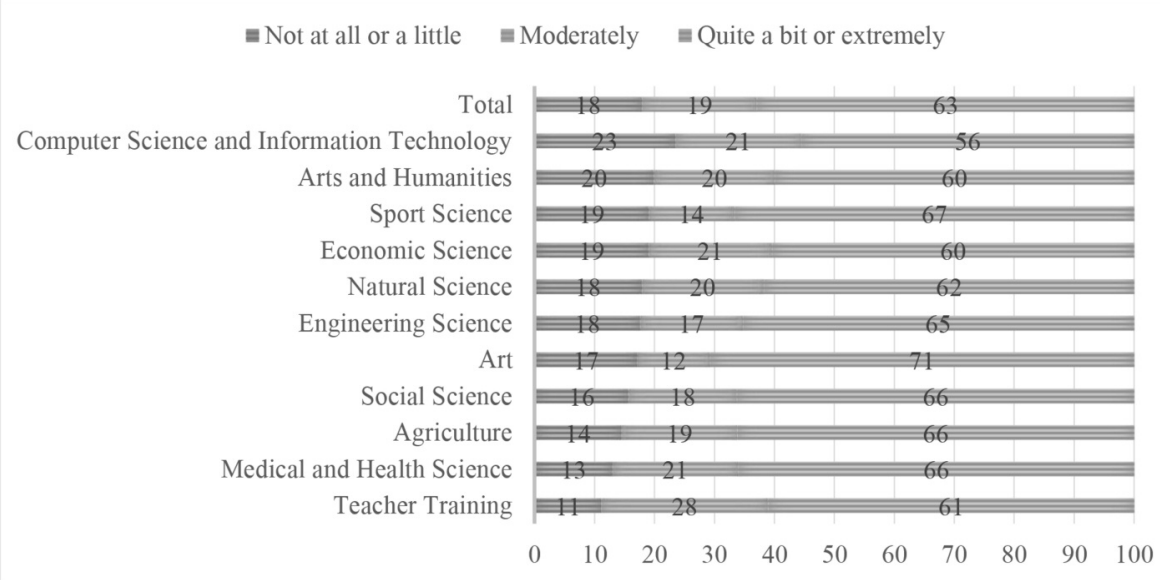

Several studies have also confirmed that students reported an increased workload during distance education (Farnell et al., 2021). According to the survey, nearly 41 per cent of international students have spent more time, and 34 per cent spend the same amount of time on learning as before the switch to distance learning. Conversely, a smaller proportion of international students, nearly 26 per cent, responded that they spent less time on learning than before the pandemic outbreak. 
Table 5. Has your time spent on learning changed during the period of distance education? $(\mathrm{N}=7,994)$

\begin{tabular}{|l|c|c|}
\hline & Frequency & Percent \\
\hline $\begin{array}{l}\text { It has not changed, I spent as much time as } \\
\text { before the period of distance education }\end{array}$ & 2,701 & $34 \%$ \\
\hline Yes, I spent less time on learning. & 2,045 & $26 \%$ \\
\hline Yes, I spent more time on learning & 3,248 & $41 \%$ \\
\hline
\end{tabular}

Several causes and factors can lead to a change in workload. One of the contributing causes, for example, is the study level at which students were studying. Most master students reported having a larger workload since the transition to distance education. The undergraduate students show a similar picture to master students; the rate of respondents with the increased workload is high, nearly 42 per cent.

In contrast, the change in workload shows a different picture in the case of doctoral students. Most of them assessed that their workload had not changed, and they spent as much time as before the period of distance education. The structure of research-focused doctoral programs can explain this tendency. The data reflect well the two phases (doctoral course and degree award procedure) of the PhD programs (Eurydice, 2021). The doctoral students who started their studies between 2017 and 2018 and might not start the degree award procedure responded that their workload had increased during the pandemic.

Table 6. Changes in workload by study levels $(N=7,568, p<0.05)$

\begin{tabular}{|l|c|c|c|}
\hline \multicolumn{4}{|c|}{ Has your time spent on learning changed during the period of distance education? } \\
\hline & Less time & $\begin{array}{c}\text { As much time } \\
\text { as before }\end{array}$ & More time \\
\hline Undergraduate students & $26 \%$ & $32 \%$ & $42 \%$ \\
\hline Master students & $24 \%$ & $34 \%$ & $43 \%$ \\
\hline PhD/DLA students & $28 \%$ & $39 \%$ & $34 \%$ \\
\hline
\end{tabular}


As regards the reasons for the change, international students elaborated in an open question why their workload had changed. The students with a larger workload reported that the new learning expectations and adapting to a new learning environment required them to invest more energy and time into learning. Overall, international students stressed the importance of adaptation skills. It is also an essential factor that the students with increased workload evaluated their learning achievement higher (based on self-evaluation) than their fellow students - so, presumably, the driver for higher academic achievement is also a significant motivational factor for online learning.

Comparatively, the international students who spent less time on learning highlighted the obstacles of adaptation in their responses. These students were more likely to have difficulty creating the designated workspace and time management in the first wave of the pandemic. It is also important to mention that self-directed learning was also a challenge for these students; therefore, learning skills need to be improved. Students who struggled to stay motivated and focused spent less time learning.

\section{The immediate impact on student life}

Students' extracurricular activities, such as attending professional and sports clubs, are essential parts of student life at universities. A university is a place for building a social network, which is decisive not only during university life but also in the later stages of graduates' career, for instance, in the labour market. These activities and related student services are also important for international students' integration into the university and academic life. Student experiences are also significant in study progress. Recognizing the importance of these factors and student satisfaction with various university services due to quality management, universities have invested a lot in organizing multiple forms of extracurricular activities and student services (Scott, 2020).

The research explores what unprecedented and serious risks international students encountered during the pandemic and what kind of support services universities and other organizations have provided. Regarding the mental and psychological well-being of international students, sixty-five per cent of international students experienced stress and anxiety, but almost half of all students reported feeling alone throughout the quarantine. During the first wave, a high percentage of international students (nearly 60\%) had difficulty travelling home, and more students reported losing their jobs or having difficulty finding alternate accommodation due to the closure of dormitories. 
Table 7. Challenges and risks during the pandemic $(N=7,994)$

\begin{tabular}{|l|c|}
\hline & Percent \\
\hline Anxiety, stress & $65 \%$ \\
\hline Cancelling travel plans to the home country (flight, train, etc.) & $61 \%$ \\
\hline Isolation, loneliness & $51 \%$ \\
\hline Discrimination & $21 \%$ \\
\hline Losing the job & $16 \%$ \\
\hline Lack of health care & $13 \%$ \\
\hline Housing/Accommodation was cancelled & $10 \%$ \\
\hline
\end{tabular}

Access to basic needs 8\%Universities supported international students in several areas but focused their resources mainly on services for online teaching. Eighty-eight per cent of international students received academic support (e.g., sharing online learning materials). In contrast, the proportion of those who received mental and psychological counselling (23\%) or even language (e.g., translation of information) support (17\%) was much lower. Consistently, this may also mean less demand for these services from students. Still, it may indicate that higher education institutions were not ready to implement these services in an online environment. Recently, however, it can be seen that the institutions, recognizing the importance of these services during the period of distance education, have tried to improve this service.

\section{CONCLUSIONS}

The tendencies of international student mobility are under continuous slow changes, which have accelerated with the global health crisis. Following the pandemic outbreak, health safety became a crucial issue. Moreover, COVID-19 had significant economic and geopolitical impacts. Although health-related measures were introduced relatively quickly, the effects of fast digitalization and the switch to distant education on students and their mobility are still hard to see; the research on the topic has just started. 
The impact of the epidemic on higher education has been the subject of several recent studies. This research has sought to take a snapshot and capture the shortterm effects, but some of the results will hopefully go beyond this and provide conclusions that can be used in the medium to longer term. In accordance with other studies (ESN, 2020), this research confirmed that COVID-19 and the shift to distance education had a decisive impact on the studies of international students. However, experiences of distance education are varied, for which a number of reasons can be identified. Some of the reasons are institutional, such as the institutional management of the transition to distance education or the attitude of teachers during the first wave of the pandemic.

In addition to these, there are also structural reasons stemming from the students' social and educational backgrounds. The individual's self-evaluation and drive to learn, for example, were decisive. Likewise, the individual's ability to manage time was also a determining factor in the transition to distance learning. It can also be seen that the ability to learn independently is of paramount importance in online learning, which was not at an adequate level for many international students; this required and expected the use of new learning support-tools from the instructors.

Being a student abroad also brought some uncertainties and difficulties: most students faced stress, isolation, and loneliness. Moreover, with the move to online education, the student experience became more limited, impacting their learning and progress. At the same time, some essential services such as psychological support were insufficiently provided by a few institutions in the first wave of the epidemic.

These issues should be addressed primarily by the host institutions. Unquestionably, most universities' human and financial resources are limited. However, some actions do not require much effort or investment, but they mean great help or comfort for international students. Each HEls situation is unique and somewhat different. Hence, based on some common good practices and their capacities, they need to formulate their specific answers for these challenges. This study aimed to detect the most common, major impacts of COVID-19 experienced by international students. By identifying these main issues, host universities and countries have a better understanding of how to take action.

\section{REFERENCES}

Baer J., Martel M. (2020). Fall 2020 International Student Enrollment Snapshot. Institute of International Education.

Bilecen, B. (2020). Commentary: COVID-19 Pandemic and Higher Education: International Mobility and Students' Social Protection. International Migration, International Organization for Migration. 
DAAD Working Paper (2021). COVID-19 and the impact on international student mobility in Germany.

Erasmus Student Network. (2020). ESN releases the biggest research report on the impact of COVID-19 on student exchanges in Europe. doi: https://esn.org/ covidimpact-report

European Migration Network (2020). Impact of COVID-19 on international students in EU and OECD member states.

Eurydice. (2021). Third Cycle (PhD) Programs, Hungary, retrieved from https://eacea.ec.europa.eu/national-policies/eurydice/content/third-cycle-phdprogrammes-35_en. Accessed 1 June 2021.

Farnell, T., Skledar Matijević, A., Šćukanec Schmidt, N. (2021). The impact of COVID19 on higher education: a review of emerging evidence, NESET report, Executive Summary, Luxembourg: Publications Office of the European Union. doi: $10.2766 / 916313$

Ferencz, I. (2020). ACA Think Pieces: The world after COVID-19, retrieved from https://aca-secretariat.be/post_other_pub/aca-think-pieces-the-world-aftercovid-19-9/?yearPub=2020. Accessed 1 June 2021.

Firang, D. (2020). The impact of COVID-19 pandemic on international students in Canada. International Social Work, 63(6), pp. 820-824.

Gabriels, W., Benke-Aberg, R., (2020). Student Exchanges in Times of Crisis- Research report on the impact of COVID-19 on student exchanges in Europe. Erasmus Student Network AISBL

Hallgatói Önkormányzatok Országos Konferenciája. (2020). Távoktatás jelentés, retrieved from https://hook.hu/hu/felsooktatas/tavoktatas-jelentes-285. Accessed 1 June 2021.

Hargitai, M. D., Sasné Grósz, A., \& Veres, Z. (2020). Hagyományos és online tanulási preferenciák a felsőoktatásban - A COVID-járvány kihívásai [Traditional and online learning preferences in higher education - Challenges posed by the COVID-19 epidemic]. Statisztikai Szemle, 98, pp. 839-857. doi: 10.20311/ stat2020.7.hu0839

Hurley P., (2020). Coronavirus and international students. Melbourne, Mitchell Institute, Victoria University.

Marinoni, G., van't Land, H., Jensen, T. (2020). The impact of Covid-19 on higher education around the world. IAU Global Survey Report. International Association of Universities.

Marinoni, G., van't Land, H., \& Jensen, T. (2020). The impact of COVID-19 on higher education around the world. IAU Global Survey Report. https://www.iau- 
aiu.net/IMG/pdf/iau_covid19_and_he_survey_report_final_may_2020.pdf. Accessed 1 June 2021.

Morris, A., Hastings, C., Wilson, S., Mitchell, E., Ramia, G. and Overgaard, C. (2020). The experience of international students before and during COVID-19: Housing, work, study and wellbeing. Sydney, University of Technology Sydney.

Quacquarelli Symonds (QS) (2020). How COVID-19 is Impacting Prospective International Students Across the Globe.

Scott, P. (2020). Can we widen participation in higher education during the Covid19 pandemic? Presentation. CGHE Seminar 143.

Studyportal Analitics and Consulting, (2020). International Student Plans. The impact of Covid-19.

Super, S., \& Disseldorf, L. (2020). Covid-19 International Student Well-being Study (C19 ISWS). doi:10.5281/zenodo.3906209

Tempus Közalapítvány. (2020). Jelentkezési és továbbtanulási stratégiák a Stipendium Hungaricum program keretében [Application and continuing learning strategies under the scholarship program], retrieved from https://tka.hu/nemzetkozi/14286/jelentkezesi-es-tovabbtanulasi-strategiak-astipendium-hungaricum-program-kereteben. Accessed 15 June 2021.

UIS. (2021). The UNESCO Institute for Statistics, retrieved from http://data.uis. unesco.org/, Accessed 20 May 2021.

Universities and Colleges Admissions Service (UCAS), (2020). Statistical Releases Daily Clearing Analysis 2020.

Watermayer, R., Crick, T., Knight, C., \& Goodall, J. (2021). COVID-19 and digital disruption in UK universities: afflictions and affordances of emergency online migration. Higher Education, 81, 623-641. doi: https://doi.org/10.1007/s10734020-00561-y 